\title{
PENGARUH METODE OUTDOOR LEARNING TERHADAP HASIL BELAJAR SISWA KELAS XB PADA MATERI KLASIFIKASI MAKHLUK HIDUP DI SMA YPK BETHEL
}

\section{SARLOTA IJIE}

\author{
SMA YPK Bethel Aimas Kabupaten Sorong
}

\begin{abstract}
ABSTRAK
Hasil belajar merupakan tujuan akhir dilaksanakannya kegiatan pembelajaran hasil belajar siswa di SMA YPK Bethel Aimas Khususnya pada siswa kelas XB yang dipakai dalam penelitian ini menunjukkan bahwa hasil terakhir (pretest) yang meningkat. Penelitian ini bertujuan untuk mengetahui pengaruh pembelajaran biologi menggunakan metode outdoor learning terhadap hasil belajar siswa kelas XB di SMA YPK Bethel Aimas. Sampel yang digunakan adalah siswa kelas XB. Metodologi pendidikan yang digunakan adalah penelitian eksperimen kuantitatif dengan alasan one group pretest-postest. Instrumen yang digunakan adalah penelitian tes yang sebelumnya diuji validitas dan uji reabilitas. Hasil yang diuji validitas pada instrumen yang digunakan valid. Data tes berdistribusi normal, hasil uji T-test paired sampai pada kelas XB didapati bahwa nilai T-hitung dan T-tabel yakni 0,576 > 2,281 sehingga ada perbedaan hasil belajar siswa sebelum dan sesudah melakukan pembelajaran menggunakan metode outdoor learningdari hasil test siswa diperoleh bahwa metode outdoor learning tersebut efektif sebagai metode pembelajaran.
\end{abstract}

Kata Kunci : Hasil Belajar, Metode Outdoor Learning, Klasifikasi Makhluk Hidup

\begin{abstract}
Learning outcomes is the ultimate goal of the learning activities of student learning outcomes at YPK SMA Bethel Aimas Particularly in grade XB students used in this study shows that the last result (pretest) is increased. This study aims to determine the effect of biology learning using outdoor learning methods to the results of students studying class XB in YPK SMA Bethel Aimas. The sample used is the students of class XB. The educational methodology used is quantitative experimental research with one pretest-postest pretest. The instrument used is a test study that previously tested the validity and reliability test. The tested results of validity on the instrument used are valid. Normally distributed test data, T-test results paired up to class XB found that the value of T-count and T-table of 0.576> 2.281 so that there are differences in student learning outcomes before and after learning using outdoor learning methods of student test results obtained that outdoor learning method is effective as a method of learning.
\end{abstract}

Keywords: Learning Outcomes, Outdoor Learning Methods, Classification of Sentient Beings

\section{PENDAHULUAN}

Secara umum pengertian pendidikan merupakan usaha yang dilakukan secara sadar oleh semua elemen yang ada di sekitar kehidupan kita, baik itu orang tua, keluarga, sahabat, ataupun masyarakat secara umum, serta lembaga-lembaga pendidikan baik yang resmi dan formal yang dibentuk oleh pemerintah dan pihak yang bertanggung jawab di indonesia, ataupun lembaga-lembaga nonformal. Pendidikan sendiri bermacam-macam, ada pendidikan umum, pendidikan khusus, pendidikan kejuruan, pendidikan akademik, pendidikan profesi, pendidikan karakter, pendidikan vokasi, hingga pendidikan agama.

Sementara tujuan pendidikan secara umum adalah untuk mengubah segala macam kebiasaan buruk yang ada di dalam diri manusia menjadi kebiasaan baik yang terjadi selama masa hidup, dengan tujuan untuk meningkatkan kualitas diri menjadi pribadi yang mampu bersaing dan menjawab berbagai tantangan di masa depan. Fungsi dan tujuan pendidikan adalah untuk memberikan arahan serta pedoman bagi semua jenis pendidikan yang dilakukan. Tujuan pendidikan secara umum tertulis dalam Undang-Undang Dasar tahun 1945 (versi Amandemen) Pasal 31 ayat 3 dan 5, Undang-undang
Nornor 2 tahun 1989 Pasal 4 dan Pasal 15, serta Undang-Undang Nomor 20 Tahun 2003 Pasal 3.

Tujuan pendidikan terdiri dari 6 yaitu tujuan umum, tujuan khusus, tujuan insidental, tujuan sernentara, tujuan tak lengkap, dan tujuan perantara.

Tujuan pendidikan secara umum yaitu pendidikan yang bersifat universal dan di rumuskan berdasar kepada hakikat manusia yaitu kedewasaan, dalam arti pribadi yang integral bagi segi individualitas, sosialitas, dan moralitas sosial dan moral.Tujuan pendidikan secara khusus yaitu pendidikan adalah belajar pengtahuan, keterampilan, dan kebiasaan sekelompok orang diturunkan dari satu generasi ke generasi berikutnya melalui pengajaran, pelatihan atau penelitian.Tujuan pendidikan insedentai yaitu suatu tujuan yang terjadi secara kebetulan, tujuan pendidikan yang terjadi khusus situasi tertentu.Tujuan sementara yaitu tujuan pendidikan yang sementara di capai untuk mencapai tujuan yang lebih tinggi.Tujuan tak lengkap yaitu yang berhubungan dengan suatu aspek kepribadian tertentu seperti hanya tujuan pendidikan agama, pendidikan jasmani, pendidikan intelektual dan sebagainya. Tujuan perantara merupakan saranaatau alat untuk mencapai tujuan-tujuan yang lain. 
Peraturan Pemerintah Nomor 19 Tahun 2005 menetapkan pengertian kurikulum yang merupakan seperangkat rencana dan pengaturan mengenai tujuan, isi, dan peajaran, cara yang digunakan untuk pedoman terselenggaranya kegiatan pembelajaran agar dapat mencapai tujuan pendidikan tertentu. Kurikulurn KTSP yang di dalamnya mengaturketentuan pendidikan IPA, pendidikan IPA dibagi menjadi Kimia, Fisika danBiologi.

Pembelajaran Biologi adalah suatu proses kegiatan yang menuntut adanya aktivitas siswa dengan demikian pengembangan media harus diarahkan pada kegiatan yang ditunjang oleh alat peraga praktek dan alat observasi. Menurut pengamatan peneliti selama melakukan PPL fasilitas dan tenaga pendidik yang ada di Sekolah tersebut sudah cukup menunjang, tetapi permasalahannya terletak pada pembelajaran yang diberikan olehguru hanya terfokus didalam kelas (ruangan).Sehingga hasil belajar kurangmemuaskan.Permasalahan yang dihadapi oleh SMA YPK Bethel Aimas Kabupaten Sorong dan yang merupakan objek penelitian yang akan diteliti?Peneliti mencoba pembelajaran di luar kelas yakni outdoor learning untuk melihat hasil belajar siswa kelas $\mathrm{X}^{\mathrm{B}}$ di SMA YPK Bethel Aimas SMA YPK Bethel Aimas materi klasifikasi makhluk hidup.

Berdasarkan uraian diatas maka peneliti tertarik untuk melakukan penelitian yang berjudul "Pengaruh Metode Outdoor Learning terhadap Hasil Belajar Klasifikasi Makhluk Hidup di SMA YPK Bethel Aimas". Untuk mengetahui pengaruh metode outdoor learning terhadap hasil belajar siswa kelas $\mathrm{X}^{\mathrm{B}}$ di SMA YPK Bethel Aimas.

\section{METODE PENELITIAN}

Penelitian ini bertujuan untuk mengetahui bagaimana pengaruh metode Outdoor Learningterhadap hasil belajar siswa kelas $\mathrm{X}^{\mathrm{B}}$, penelitian ini merupakan penelitian eksperirnen yang bersifat kuantitatif berbentuk korelasional (correlational research), yang bertujuan untuk menyelidiki sejauh mana variabel-variabel pada suatu faktor berkaitan dengan variabel-vanabel pada satu atau lebih faktor lain berdasarkan pada koefisien korelasi (Narbuka dan Achmadi,2001). Sedangkan menurut sumanto dalam Ismail (2010), penelitian korelasi berkaitan dengan pengumpulan data untuk menentukan ada tidaknya hubungan antara dua variabel atau lebih dan seberapa besar tingkat hubungannya.

Dari uraian beberapa pendapat tersebut dapat diambil kesimpulan bahwa penelitian ini korelasi dengan maksud untuk mengungkapkan hubungan antara variabel yang di libatkan dalam penelitian sehingga rnendapatkan informasi yang lengkap mengenai kaitan diantara variable-variabel yang diteliti.

Dalam penelitian ini menggunakan korelasional dengan maksud untuk mengungkapkan hubungan antara variabel yang dilibatkan dalam penelitian.

\section{Indikator Outdoor Learning}

a. Memahami tentang jamur (fungi) Tiram dan jamur Merang yang berasal dari pengalaman dan pengamatan dan dilanjutkan dengan suatu pemikiran secara cermat dan teliti dengan menggunakan metode observasi, eksperirnen, survey, studi kasus dan lainlain.

b. Menganalisis data observasi (pengamatan yang diatur dan di organisasikan, mengadakan pendekatan terhadap benda-benda atau peristiwaperistiwa dengan rnenggunakan metode observasi yang teliti dan kritis.

c. Pengetahuan yang disusun berasal dari pengamatan, studi dan pengalaman untuk menentukan hakikat dan prinsip tentang hal yang sedang di pelajari.

$\mathrm{Y} \quad=$ Variabel Terikat (Hasil Belajar)

1. Output Afektif (Aktivitas siswa dalam proses pembelajaran dan Sikap) Karakter Siswa

2. Output Kognitif(Kenaikanjumlah siswa dalam peningkatan nilai)

Paradigma ganda dengan satu variabel independen dan dua dependen. Untuk mencari besarnya hubungan antara $\mathrm{X}$ dan $\mathrm{Y}$, digunakan teknik korelasi sederhana..Analisis regresi juga dapat digunakan di sini. $\mathrm{rXY}=$ Korelasi $\mathrm{XY}$

Penelitian ini dilaksanakan di SMA YPK Bethel Aimas KabupatenSorong.Untuk pelajaran Biologi pada materi pokok Klasifikasi Makhlukhidup kelas $\mathrm{X}^{\mathrm{B}}$.Penelitian ini dilaksanakan pada tanggal 06 Juli - 20 Agustus 2017.

Dalam peneitian ini sampel yang digunakan adalah siswa kelas $\mathrm{X}^{\mathrm{B}}$ dengan jumlah siswa sebanyak 20 siswa di SMA YPK Bethel AImas Kabupaten Sorong.

Instrumen yang digunakan dalam penelitian ini terdiri atas tiga yaitu Tes,observasi,dan Dokumentasi.

\section{Tes}

Merupakan sejumlah pertanyaan atau latihan serta alat yang lain untuk dapat mengatur ketrampilan, pengetahuan, dan kemampuan yang dimiliki oleh peserta didik. Yuliati (2011) tes dapat digunakan untuk memperoleh data tentang hasil belajar.Bentuk tes yang digunakn dalam penelitian ini berupa tes pilihan ganda dengan jumblah 10 soal yang diberikan setelah perlakuan (menggunakan metode out door learning).

\section{Observasi}

Observasi digunakan untuk dapat memperoleh data tentang keadaan dan fasilitas yang ada. Yuliati (2011) observasi merupakan cara untuk menghimpun data (keterangan) yang dilakukan dengan mengadakan pengamatan dan pencatatan secara sistematis terhadap fenomena yang menjadi sasaran pengamatan. Dokumentasi digunakan untuk memperoleh data berupa jumlah dan nama-nama peserta didik serta hal lain. 


\section{Dokumentasi}

Dokumentasi merupakan metode yang digunakan untuk mencari data melalui peninggalan tertulis, seperti buku arsip, teori dan lain-lain yang berhubungan dengan masalah penelitian (Margono 2011).

Teknik pengumpulan data

a. Pemberian pretest (tes awal) sebelum menggunakan metode out door learning .

b. Pemberian Postest (tesakhir) setelalah menerapkan metode out door learning .

c. Membuat catatan kecil agar dapat mengetahui prestasi (hasil belajar) siswa kelas $\mathrm{X}^{\mathrm{B}}$ diSMA YPK Bethel Aimas sebelum dan sesudah menggunakan metode out door learning .

Untuk memudahkan dalam proses perhitungan, maka perhitungan uji validitas dilakukan dengan menggunakan bantuan program SPSS 20 yaitu menghitung koefisien korelasi antara item anket total item.

Menurut Sugiyono (2011), syarat minimum untukdianggap memenuhi syarat adalah $\mathrm{R}=0,3$. Jadi kalau korelasi antar butir dengan skor total $<0,3$ maka butir instrumen tersebut dinyatakan tidak valid, sedangkan apabila $\mathrm{R}$ hitung $>0,3$ maka butir instrurnen tersebut valid. Untuk item angket yang tidak valid selanjutnya dibuang dan tidak digunakan dalam pengumpulan data.

Realibilitas suatu alat ukur atau alat evaluasi dimaksudkan sebagai suatu alat yang memberikan hasil yang sama. Suatu test dikatakan reliable jika hasil evaluasi tersebut relatif tetap jika digunakan untuk subyek yang sama dalam waktu yang berlainan. Untuk mempermudah dalam mengolah data perhitungan peneliti menggunakan bantuan program SPSS 20 yaitu menghitung koefisien kolerasi dengan teknik bela dua (Spilt Half).

Data yang terkumpul dalam penelitian ini di analisis dengan menggunakan aplikasi statistik untuk mempermudah penelitian dalam perhitungan.Untuk mengetahui peningkatan Prestasi Belajar dan motivasi siswa dibuat seperangkat soal tes berbentuk pilihan ganda, yang terdiri dan 20 butir soal.Instrument yang dikembangkan sendiri oleh peneliti, karena peneliti memberikan soal sesuai dengan keadaan siswa dan sesuai dengan materi yang telah disampaikan atau dibahas sehingga diharapkan hasilnyapenjumlahan penyimpangan data observasi kelas dengan nilai yang diharapkan.

Sebaran data dikatakan baik jika data tersebut berdistribusi normal.

Uji Homogenitas dilakukan untuk mengetahui perbedaan antara dua kelompok atau populasi memiliki tingkat varian yang sama atau tidak, uji homogenitas yang digunakan adalah uji Fisher.

Uji Validitas Validitas merupakan suatu ukuran yang dapat menunjukkan kevalidan (kesahahan) suatu instrument.Sebuah item dikatakan valid apabila mempunyai dukungan yang besar terhadap skor total.
Kaidah keputusan : Jika $t_{\text {hitung }}>t_{\text {tabel }}$ berarti signifikan (valid) sebaliknyathitung $<\mathrm{t}_{\text {tabel }}$ berarti tidak valid.

Menurut Sugiyono (2011), syarat minimum untuk dianggap memenuhi syarat adalah $\mathrm{R}=0,3$. Jadi kalau korelasi antar butir dengan skor total $<0,3$ maka butirinstrumen tersebut dinyatakan tidak valid, sedangkan apabila $R_{\text {hitung }}>0,3$ maka butir instrurnen tersebut valid. Untuk item yang tidak valid selanjutnya harus di revisi atau tidak digunakan dalam pengumpulan data.

Reliabilitas merupakan istrumen yang dapat mengukur sesuatu yang yang diukur secara konsisten dan waktu ke waktu. Kriteria suatu instrument penelitian dikatakan reliable bila koefisien reliabilitas $\mathrm{r}_{11}>0,6$ atau dibandingkan dengan $\mathrm{r}$ tabel (Product moment) jika niai reliabilitas Alpha Cronbach > r tabel maka dikatakan Reliabel, dan sebaliknya.

\section{Uji Hipotesis Signifikan}

Signifikan uji, nilai post test di bandingkan dengan pre test (chi-square).

Jika nilai post test $<$ nilaipre test, maka: Ha diterima, Ho ditolak.

Jika nilai post test> nilai pre test, maka: Ha ditolak, Ho diterima.

Uji One sampel membutuhkan sebuah sampel (variabel) dan nilai perkiraan sebelurnnya. Rurnus uji t-1 sampel:

\section{PEMBAHASAN}

Penelitian dilakukan di SMA YPK Bethel Airnas Kabupaten Sorongdengan judul Pengaruh Metode Outdoor Learning terhadap hasil belajar siswa kelas $\mathrm{X}^{\mathrm{B}}$ pada materiKlasifikasi makhluk hidup pada tahun ajaran 2016/2017 semester genap SMA YPK BETHEL AIMAS terletak pada Distrik Aimas Kabupaten Sorong Provinsi Papua Barat, pada sekolah ini terdiri atas 5 (lima) kelas dengan jumlah siswa keseluruhan kelas X sebanyak 103 siswa. Adapun kelas $\mathrm{X}^{\mathrm{B}}$ yang merupakan sampel dengan jumlah siswa putri sebanyak 11 (sebelas) orang dan putra sebanyak 9 (sembilan orang).

Data Penelitian yang dilakukan berupa Tes Awal dan Tes Akhir siswa kelas $X^{\mathrm{B}}$ untuk mengetahui pengaruh metode pembelajaran Outdoor Learning, Tes Awal dilakukan sebelum siswa diberi Perlakuan" tidak Menggunakan Metode Outdoor Learning "untuk dapat mengetahui hasil belajar siswa setelah diberikan perlakuan " Menggunakan metode outdoor learning " maka peneliti memberikan tes akhir. Hasil tes sebelum dan sesudah perlakuan yang di berikan kepada siswa kelas $\mathrm{X}^{\mathrm{B}}$ berupa Tes Uraian, Berikut Adalah Deskripsi data skor siswa kelas $\mathrm{X}^{\mathrm{B}}$. Visi sekolah : 1. Unggul dalam mutu, beriman, sikap peduli dan berbudaya. Lingkungan, serta mampu bersaing di era global.

Misi sekolah :

1. Meningkatkan keimanan dan ketaatan terhadap Tuhan yang maha kuasa, serta nilai-nilai budaya sehingga menjadi sumber kearifan dalam bertindak. 
2. Mengembagkan pembelajaran yang efektif , kreaktti, dan menyenangkan bagi siswa dan guru, sehingga bisa mengembangkan semua potensi yang dimiliki siswa secara optimal.

3. Menumbuhkembangkan budaya mutu sehingga mampu bersaing di era global.

4. Menumbuhkembangkan sikap peduli, sadar lingkungan melalui pembelajaran yang berkelanjutan.

Instrurnen tes awal diberikan Kepada siswa sebelumdi berikan perlakuan "Tidak Menggunakan Metode Outdoor Learning" untuk mengetahui hasil belajar siswaberikut adalah data Hasil Pemberian Tes Awal Siswa Kelas $X^{\mathrm{B}}$.

Tabel 4.1Hasil Pre test kelas $X^{B}$

\begin{tabular}{|c|c|}
\hline Statistik Deskriptif & $\begin{array}{c}\text { Perolehan Skor } \\
\text { Kelas } \mathbf{X}^{\mathbf{B}}\end{array}$ \\
\hline Jumlah Siswa & 20 \\
Maximum (X max) & 80 \\
Minimum (X min) & 40 \\
Mean (Sum) & 1230 \\
\hline
\end{tabular}

Berdasarkan Tabel 4.1 Menunjukan bahwa pada tes akhir siswa Kelas XB yang berjumlah 20 Siswa Memperoleh nilai terendah 40, Niiai Tertinggi 80, Dan Jumlah Nilai keseluruhan Siswa Yaitu 1230.

Tabel 4.2 Hasil Nilai Pretes Kelas $X^{B}$

\begin{tabular}{|c|c|c|}
\hline Nilai & KKM & Keterangan \\
\hline 30 & 70 & TL \\
40 & 70 & TL \\
60 & 70 & TL \\
50 & 70 & TL \\
50 & 70 & TL \\
70 & 70 & L \\
50 & 70 & TL \\
60 & 70 & TL \\
40 & 70 & TL \\
60 & 70 & TL \\
50 & 70 & TL \\
50 & 70 & TL \\
\hline
\end{tabular}

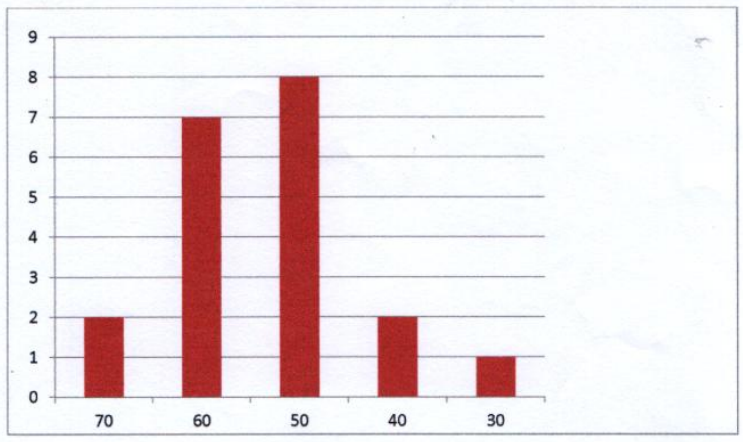

Gambar 4.7 Grafik Distribusi Skor Awal

Berdasarkan Grafik Skor awal di atas diperoleh data sebagai berikut: Siswa yang mendapat nilai 70 terdiri dari 2 Siswa yang mendapat Nilai 60 terdiri dari 7 Siswa, Yang mendapat Nilai 50 terdiri atas 8 siswa, Nilai 40 Berjumlah 2 siswa dan nilai 30 berjumlah 1 Siswa.
Setelah pemberian tes awal sampel Akhir diberikan perlakuan "Menggunakan Metode Outdoor learning Untuk mengetahui apakah ada perbedaan antara hasil tes awal dan hasil tes akhir, Berikut adalah Hasil Tes Akhir Siswa Kelas X B

Tabel 4.3 Hasil Postes Siswa kelas XB

\begin{tabular}{|c|c|}
\hline Statistik Deskriptif & $\begin{array}{c}\text { Perolehan Skor } \\
\text { Kelas X }^{\mathbf{B}}\end{array}$ \\
\hline Jumlah Siswa & 20 \\
Maximum (X max) & 80 \\
Minimum (X min) & 40 \\
Mean (Sum) & 1230 \\
\hline
\end{tabular}

Berdasarkan Tabel 4.6 Menunjukan bahwa pada tes akhir siswa Kelas XB yang berjumlah 20 Siswa Memperoleh nilai terendah 40, Niiai Tertinggi 80, Dan Jumlah Nilai keseluruhan Siswa Yaitu 1230.

Berdasarkan Grafik tersebut Skor Akhir Siswa kelas X B Yang mendapat nilai 80 sebanyak 3 Siswa, Nilai 70 sebanyak 7 siswa , Nilai 60 Sebanyak 6 Siswa, Nilai 50 Sebanyak 2 Siswa, Dan Nilai $40=1$ siswa.

\section{Tabel 4.5 Hasil Nilai Postes Kelas $X^{B}$}

\begin{tabular}{|c|c|c|}
\hline Nilai & KKM & Keterangan \\
\hline 50 & 70 & TL \\
60 & 70 & TL \\
60 & 70 & TL \\
70 & 70 & L \\
80 & 70 & L \\
70 & 70 & L \\
70 & 70 & L \\
40 & 70 & TL \\
50 & 70 & TL \\
60 & 70 & TL \\
80 & 70 & L \\
70 & 70 & L \\
60 & 70 & TL \\
60 & 70 & TL \\
80 & 70 & L \\
70 & 70 & L \\
60 & 70 & TL \\
60 & 70 & TL \\
70 & 70 & L \\
80 & 70 & L
\end{tabular}

Uji Validitas soal di gunakan untuk mengetahuikevalidan suatu instrumen responden yang di gunakanSebanyak 20 Siswa di SMA YPK Bethel AimasKabupaten Sorong yang tidak mendapat perlakuan berdasarkan hasil analisis menunjukan bahwa nilaikorelasi untuk soal No : 1,2,3,4,9,11,12,13,15,16,17,19, dan $20>0,340$ Maka Soal tersebut berkorelasisignifikan adalah valid dan untuk soal No: 5,6,7,8,10,14, dan $18<0,340$ maka soal tersebut berkorelasi tidaksignifikan ( Tidak valid).

Uji reliabilitas soal dilakukan untuk mengetahuiapakah sebuah instrumen dapat mengukur 
sesuatu yang di ukur secara konsisten dan waktu data hasil uji.

Sebelum dilakukan pengolahan data lebih lanjut maka dilakukan uji prasyarat yaitu uji normalitas berikut adalah normalitas awal dannormalitas akhir siswa kelas $\mathrm{X}^{\mathrm{B}}$.

Uji normalitas data siswa awal kelas $\mathrm{XB}$ berdasarkan rumus klologrof-smirnov signifikan 0,05 dengan demikian dapat disimpulkan data tersebut tidak normal

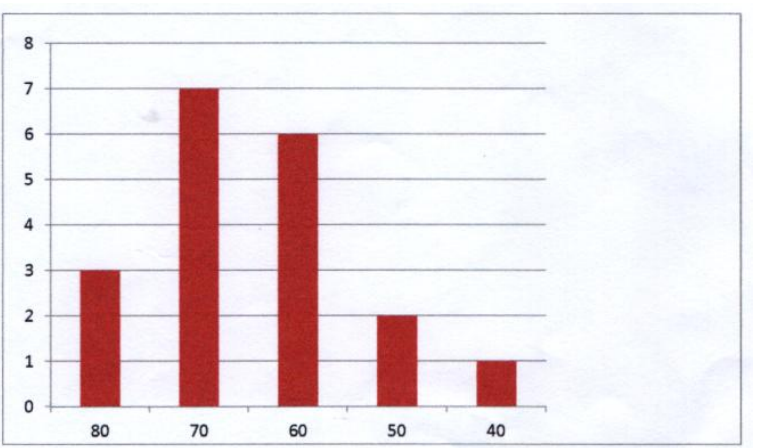

Uji normalitas data tes awal siswa kelas $\mathrm{X}^{\mathrm{B}}$ awal diperoleh hasil berdasarkan rumus ShapiroWilk signifikan > 0,904 dengan demikian data disimpulkan bahwa data tersebut berdistribusi normal.

Uji normalitas tes akhir siswa kelas $\mathrm{X}^{\mathrm{B}}$ akhir diperoleh data berdasarkan rumus Shapiro Wilk signifikan 0,904>0,906 maka dapat disimpulkan bahwa data tersebut berdistribusi normal.

Instrumen diberlakukan Kepada 20 siswa di SMA YPK Bethel Aimas Kabupaten Sorong.

Hasil Menunjukan Bahwa Nilai $r$ hitung $=0,649$ Kemudian di bandingkan Menggunakan $\mathrm{r}$ hitung 0,456Maka hasil Yang di dapat adalah $\mathrm{R}$ hitung $=0,625>$ Rtable $=0,456$ Jadi Soal tersebut dianggap Reliabel dan dapat digunakan sebagai Instrumen.

Hasil yang diperoleh $0,20>0,05$ maka pretes kelas $\mathrm{X}^{\mathrm{B}}$ memiliki varians data homogen.

Uji hipotesisi berdasarkan hasil menunjukkan data tes awal dan tes akhir siswa kls $\mathrm{X}^{\mathrm{B}}$ berdistribusi tidak normal, namun saat pengujian prasyarat uji homogenitas data tersebut homogen.Uji hipotesis dapat dilakukan rnenggunakan uji man-whhitnay. Hipotesis yang dimaksud yaitu:

$\mathrm{Ha}=\quad$ Nilai sebelum dan sesudah pemberlakuan pernbelajaran lingkungan sekitar sekolah (metode out door learning) sama.

Ho $=\quad$ Nilai sebelum dan sesudah pemberlakuan pembelajaran lingkungan sekitar sekolah (metode out door learning)tidaksama.

Syarat Ho diterima atau tidak berdasarkan $\mathrm{T}$ hitung sebagai berikut: Apabila probabilitas > 0,05 maka Ho diterima dan $\mathrm{Ha}$ ditolak. Apabila probabilitas < 0,05 maka Ho diterima dan Ha ditolak

Dari hasil pada baris simpang terlihat bahwa nilai probabilitas 0,000 maka keputusan hasil adalah $0,000<0,059$ berarti H0diterima jadi nilai sebelum dan sesudah pembelajaran aplikasi lingkungan alarn sekitar sekolah tidak sama.

Hasil analisis di isntrumen soal menunjukkan bahwa dari 20 soal dinyatakan valid 13 sedangkan 7 soal tidak valid.Uji rehabilitas diperoleh hasil yang realiabel sehingga dapat digunakan sebagai instrumen. Hasil uji homogenitas seluruh siswa kelas $\mathrm{X}^{\mathrm{B}}$ nilai pretest dan posttest adalah homogen, maka hasil uji homogenitas tersebut dapat digunakan lagi sebagai data penelitian.

Uji normalitas menyatakan bahwa tidak sernua distribusi normal, namun pada saat pengujian prasyarat homogenitas, semuadata dinyatakan homogen dan hipotesis yang digunakan adaiah uji ttes paired sampel.

Hasi penelitian siswa kelas $\mathrm{X}^{\mathrm{B}}$ diperoleh fakta berdasarkan uji hipotesisi adalah $r$ hitung 0,649 jikadibandingkan dengan $\mathrm{r}$ tabel 0,456 dengan $\mathrm{df}=19$ makahasil yang diperoleh yaitu $0,649>\mathrm{r}$ tabel $=0,456$ rnenerangkan bahwa Ho diterima dan ada perbedaanterhadap hasilpembelajaran menggunakan metodeoutdoor learning sehagai media pembelajaran.

Hasil dapat dilihat pada gambar 4.4 sekarang awalsiswa sekolah setelah mendapat perlakuan siswa dan testterakhir dan hasil menunjukkan bahwa dan 20 siswa yangsetuju hasil data dan rata-rata $=1230$ dapat dilihat tabel4.7.

Uji normalitas data tes awal siswa kelas $\mathrm{X}^{\mathrm{B}}$ dan hasilRumus kolmogrov-sirnov signifikan $0,000<0,05$ daripadapengujian normalitas data test siswa diperoleh hasilberasarkan rumus kolmogrov-sirnov signifikan $0,000<0,005$ maka dapat disimpulkan bahwa data tersebutterdistribusi tidak normal.

\section{KESIMPULAN}

Kesimpulan pada penelitian ini dalah :

1. Pembelajaran siswa kelas $\mathrm{X}^{\mathrm{B}}$ hasil tes awal dan tes akhir siswa terdapat perbedaan membuktikan pada hasil hipotesis uj i t-test paired yang menunjukkan bahwa nilai $r$ hitung $=0,649$ jika dibandingkan dengan $\mathrm{r}$ tabel $=0,456$ maka hasil yang diperoleh yakni $r$ hitung $0,649>\mathrm{r}$ tabel 0,456 . Nilai sebelum dan sesudah pemberlakuan metode pembelajaran outdoor learning terdapat perbedaan atau tidak sama.

2. Penggunaan metode outdoor learning berpengaruh terhadap hasil belajar siswa, hal ini sesuai dengan hasil perhitungan menggunakan uji ttes sampel yang telah diperoleh hasil.

Faraziah (2015) Penelitian menunjukkan bahwa pembelajaran menggunakan Metode Out Door Learning lebih meninggkat di bandingkan dengan menggunakan metode Konvensional.

Ningrum (2009) Hasil penelitian yakni metode Out Door Study sangat berpengaruh hal ini di buktikan dengan rata-rata nilai pada pengujian Hipotesis di peroleh $\mathrm{F}$ hitung $(3,114)>\mathrm{F}$ Tabel $(14,00)$ yang berarti sangat berpengaruh. 


\section{DAFTAR PUSTAKA}

Achmadi, (2001).Jenis dan Desain Penelitian dan Kuantitatif.Bandung : Alfabeta.

Azwar,( 2012 ). Reliabilitas dan Validitas. Penerbit Pustaka Pelajar:Yogyakarta.

Basrowi dan Sudjarwo, ( 2009 ). Manajemen Penelitian Sosial. Penerbit CV. Mandar Maju: Bandung.

D.A.Pratiwi dkk (2014).Biologi untuk SMA/MA kelas $X$. Penerbit Erlangga.

Rurnaylis ( 2011 ). Dasur Dasar Kependidikan. Penerbit Kaamulia:.Yogyakarta.

Kebijakan Pendidikan ( 2012 ). PenerbitPustaka Pelajar. Yogyakarta.

Hariwijaya ( 2007 ). Melodologi dan Penulis Skripsi untuk i/mu Sosial dan Hurnaniora. Penerbit Pararna Ilmu: Yogyakarta.

Mudayei ( 2013 ). Vilsa/Pendidikan penerbil PT. Refrika Aditama:. Bandung.

Ali( 1982 ) Penelitian Kepandidikan Prosedur dan Sirategi. Penerbit Angkasa: Bandung.

Kasdin (2016) Pengaruh Amplikasi Pembelajaran Berbasis A/am Sekilar Terhadap Hasil Belajar Biologi Siswa Kelas VIII SMP Negeri 10 Kabupaten Sarong. Sorong: STKIP MUhammadiyah Sorong.

Noeng, Muhadjir (2003). Melodoogi penelitian Kebijakan dan Evamupran Recearch. Penerbit Rako sarasan: Yogyakarta.
Peminatan IPA dan Matematika ( 2013 ). Penerbit Erlangga: Jakarta.

Paulo Freire (2007). Konsep Metode Outdoor Learning. Penerbit Alfabeta : Bandung.

Rasyad, A ( 2003 ) Teori Belajar dan Pembelajaran. Penerbit Uhamka Press:Jakarta.

Sagala, Syaiful (2014). Konsep dan Makna Pembelajaran. Penerbit Alfa Beta:Bandung(2014). Supervise Pembelajaran dalam provesi pendidikan. Penerbit Alfa Beta: Bandung.

Sisdiknas (Sistem Pendidikan Nasional ) 2005. Penerbit Fokus Media: Bandung Sukukidin (2005). Metode Penelitian. Penerbit Isic: Surabaya.

Suyata ( 1996 ). Penyusun Kerangka Penelitian :suatu panduan singkatPPSIKKIP : Yogyakarta.

Sugiyono (2015).Metode Penelitian dan pengembangan. Bandung: Alfabeta.

Sudjana (2010).Media Pembelelajaran. Bandung: Sinar Baru.

Surya (1981).Belajar dan Pembelajaran.Bandung : Sinar Baru.

Undang-Undang No.22 Tahun 2003 tentang Sistem Pendidikan Nasional.

Undang-Undang NO. 19 Tahun 2005 Kurikulum.

Undang-Undang No. 20 Tahun 2005 Pendidikan.

Yuliati (2011).Psikologi Pendidikan Dengan pendekatan Baru.Bandung Remaja Rosdakarya

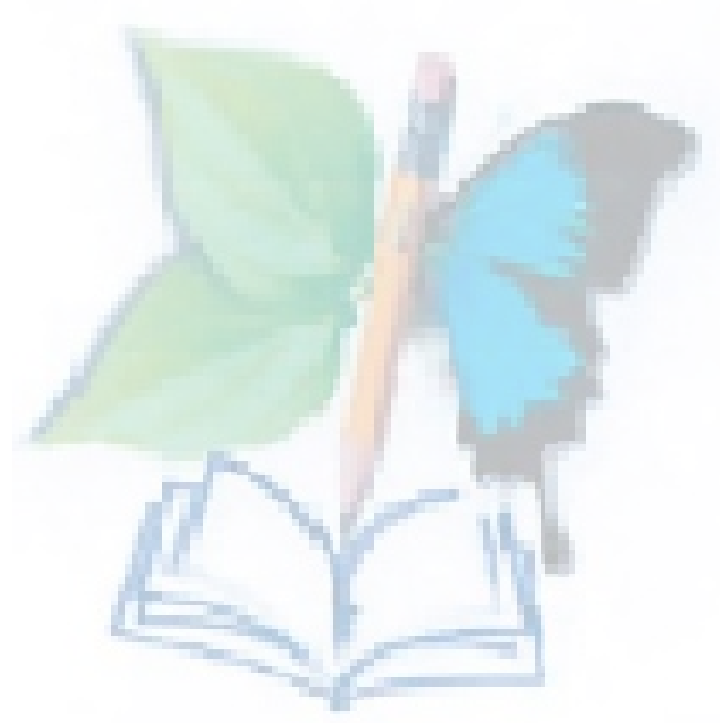

